ISSN 0258-7122

Bangladesh J. Agril. Res. 40(3): 479-489, September 2015

\title{
VARIABILITY, CORRELATION AND PATH ANALYSIS IN PUMPKIN (Cucurbita moschata L.)
}

\author{
S. SULTANA ${ }^{1}$, M. A. KAWOCHAR ${ }^{2}$, S. NAZNIN ${ }^{3}$ \\ A. SIDDIKA ${ }^{4}$ AND F. MAHMUD ${ }^{5}$
}

\begin{abstract}
Twenty one genotypes of pumpkin (Cucurbita moschata L.) were evaluated to measure the variability among the genotypes for several characters, estimate genetic parameters, association among the characters and their contribution to yield. There was a great deal of significant variation for all the characters among the genotypes. High variability was observed in number of female flowers/plant, number of male flowers/plant, single fruit weight and fruit yield/plant. All the characters except days to first male flowering and days to first female flowering showed high heritability along with high genetic advance in percent of mean. The positive and strong association of number of female flowers/plant $\left(\mathrm{r}_{\mathrm{g}}=0.918\right.$, $\left.r_{p}=0.839\right)$, number of male flowers/plant $\left(r_{g}=0.687, r_{p}=0.638\right)$, fruit length $\left(r_{g}=0.691, r_{p}=0.520\right)$, fruit breadth $\left(r_{g}=0.518, r_{p}=0.420\right)$ and single fruit weight $\left(r_{g}=0.492, r_{p}=0.431\right)$ with fruit yield/plant revealed the importance of these characters in determining fruit yield/plant. On the other hand, days to first male flowering $\left(\mathrm{r}_{\mathrm{g}}=-0.623, \mathrm{r}_{\mathrm{p}}=-0.550\right)$ and days to first female flowering $\left(\mathrm{r}_{\mathrm{g}}=\right.$ $\left.0.689, r_{p}=-0.543\right)$ correlated significantly and negatively with fruit yield/plant. The path co-efficient analysis revealed that the highest positive direct effect was recorded in number of female flowers $(0.887)$ to fruit yield and high direct effect was found in case of days to first female flowering (0.798). Fruit breadth was observed to have the highest positive indirect effect (0.899). In case of fruit length (0.381) and single fruit weight (0.398), the significant positive correlation with fruit yield/plant was observed because of the combination of the direct and indirect effects of fruit length and single fruit weight to fruit yield/plant. Overall, the results indicated that days to first female flowering, number of female flowers, fruit length, fruit breadth and single fruit weight can be used as useful selection criteria to increase fruit yield/plant in pumpkin.
\end{abstract}

Keywords: Pumpkin, variability, Correlation, Path co-efficient analysis.

\section{Introduction}

Pumpkin (Cucurbita spp.) is one of the cucurbitaceous fruit vegetables of Bangladesh. It is an important source of minerals, fibres, vitamins, antioxidants and phytonutrients (Aruah et al, 2010) and these make the fruit a whole-some and healthy item for human consumption. Some authors have reported that

\footnotetext{
${ }^{1-3}$ Scientific Officer (Plant Breeding), Tuber Crops Research Centre, Bangladesh Agricultural Research Institute (BARI), Gazipur-1701, ${ }^{4}$ Scientific Officer, Oilseed Research Centre, BARI, Gazipur-1701, ${ }^{5}$ Professor, Department of Genetics and Plant Breeding, Sher-e-Bangla Agricultural University, Dhaka-1207, Bangladesh.
} 
pumpkin fruits possess high medicinal values (Abd El-Aziz and Abd El- Kakek, 2011). Pumpkin seed is an excellent source of protein and has pharmacological values such as anti-diabetic ( $\mathrm{Li}$ et al, 2003), antibacterial and antiinflammation activities (Fu et al, 2006) and antioxidant effects (Nkosi et al., 2006). Despite its health and dietary benefits, the production of pumpkin in Bangladesh is mostly done on a small scale with low yield. The total production of pumpkin was 0.218 million tons in 2011 in this country (BBS, 2011). However, cultivation of this crop is highly desirable to overcome the problems of under-nourishment and food poverty in Bangladesh. A large number of pumpkin genotypes are cultivated in Bangladesh but no serious attempts have been made to improve its productivity and acceptability.

The success of any crop improvement program depends, to a large extent, on the amount of genetic variability present in the population. Intensive research efforts are needed in several areas particularly in selection of superior pumpkin genotypes. There is a wide genetic variability among the existing genotypes (Aliu et al, 2011) and thus, the utilization of such variability in the breeding programs of this crop is possible. In a crop selection program, knowledge of the interrelationships among yield and yield contributing characters are necessary. Path analysis would help in partitioning the correlation coefficient into direct and indirect effects of various traits on the genetic variability, character association and the direct and indirect contributions of some yield characters towards fruit yield. Thus, the present investigation was undertaken with the view to estimate variability and character association in pumpkin.

\section{Materials and Method}

The investigation was carried out at the experimental field of Sher-e-Bangla Agricultural University, Dhaka, Bangladesh during the period from March to August 2010 to study the variability and character association in 21 pumpkin genotypes. The experiment was laid out in Randomized Complete Block Design (RCBD) with three replications. These genotypes were assigned at random into pits of each replication. Pits of $55 \mathrm{~cm} \times 55 \mathrm{~cm} \times 50 \mathrm{~cm}$ were prepared in each block at a spacing of $3 \mathrm{~m} \mathrm{x} 3 \mathrm{~m}$. Standard production package was followed for raising a healthy crop. For studying different genetic parameters and inter-relationships, thirteen characters were taken into consideration namely, leaf length, leaf breadth, internodes distance, days to first male flowering, days to first female flowering, pedicel length of male flower, pedicel length of female flower, number of male and female flowers/plant, fruit length, fruit breadth, single fruit weight and fruit yield plant ${ }^{-1}$. Analysis of variance (ANOVA), mean and range were calculated by using MSTATC software program. Phenotypic and genotypic variances were estimated by the formula given by Johnson et al, (1955). Genotypic and phenotypic co-efficients of variations were calculated 
using the formula of Burton (1952) and the values were categorized as low (0$10 \%)$, moderate(10-20\%) and high (20\% and above) as suggested by Shivasubramanian and Menon (1973). Heritability was measured using the formula given by Singh and Chaudhary, (1985) and the percentage was categorized as low $(0-30 \%)$, moderate $(30-60 \%)$ and high $(60 \%$ and above) as given by Robinson et al, (1949). Genetic advance in percentage of mean was calculated by the formula given by Johnson et al, (1955), and the values were categorized as low (0-10\%), moderate (10-20\%) and high (20\% and above) as given by him. Genotypic and phenotypic correlation coefficients were obtained using the formula suggested by Miller et $a$,. (1958), and path co-efficient analysis was done following the method outlined by Dewey and $\mathrm{Lu}$ (1959).

\section{Results and Discussion}

Genetic Variability: Variance components, genotypic and phenotypic coefficients of variations, heritability, genetic advance and genetic advance in percent of mean (GAPM) are presented in Table 1. The phenotypic variance and phenotypic coefficient of variation were higher than the corresponding genotypic variance and genotypic coefficient of variation for all the characters under study suggesting the presence of environmental influence to some extent in the expressions of these characters. The highest genotypic variance (57.87) as well as phenotypic variance (85.62) was found in fruit length followed by days to first male flowering and days to first female flowering. Saha et al, (1992) also found high genotypic variance (30.34) and phenotypic variance (31.76) in fruit length.

The difference between genotypic variance and phenotypic variance was the minimum in single fruit weight indicating that less influence of environment on this character. The highest genotypic (45.76) and phenotypic co-efficients of variation (69.78) were found in number of female flowers/plant, which indicated that the genotypes were highly variable for this trait. High variability was also observed in internode distance, pedicel length of male flower, pedicel length of female flower, number of male flowers/plant, single fruit weight and fruit yield/plant. All the characters except days to first male flowering and days to first female flowering showed high heritability along with high genetic advance in percent of mean. High heritability estimates for the characters like pedicel length of male flower (96.49), pedicel length of female flower (95.94), single fruit weight (81.20) and fruit yield/plant. On the other hand, genetic advance for these characters were $71.39,82.02,65.55$ and 106.73 , respectively. Chowdhury and Sharma (2002) found high values of heritability, PCV, GCV and genetic advance for yield/ha and single fruit weight. High heritability with high genetic advance in percent of mean indicated that the character is mostly governed by additive genes, and selection based on this character would be effective for future breeding program. 


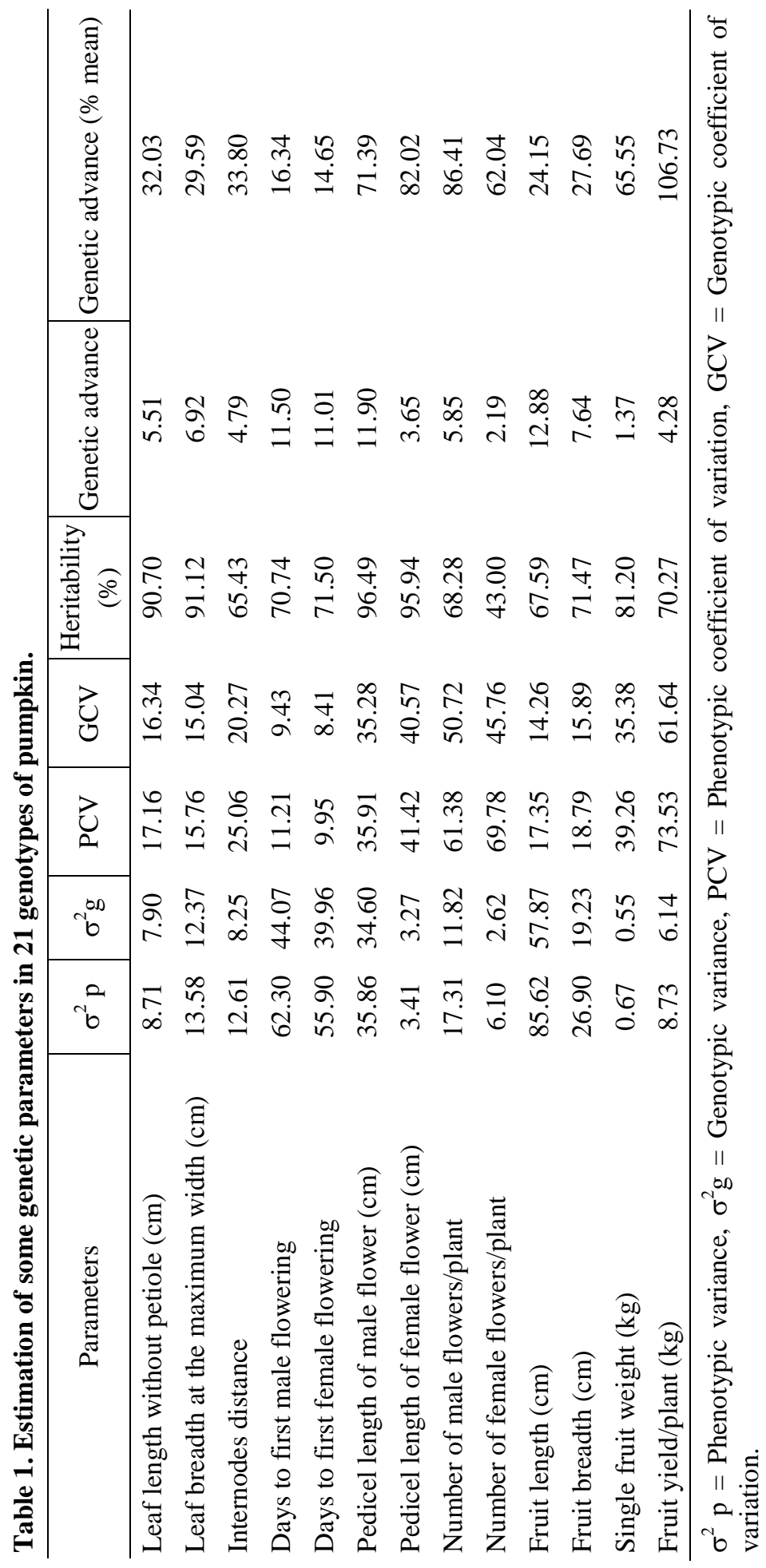


High heritability and moderate genetic advance in percent of mean found in days to first male flowering $(70.74,16.34)$ and days to first female flowering $(71.50$, $14.65)$ indicated the non-additive gene effect. Therefore, high heritability does not necessarily mean that the character will show high genetic advance. Selection based upon phenotypic expression of these characters would not be effective for the improvement of this crop. Singh and Lal (2005) reported similar results.

Correlation co-efficient: Correlation studies have been done both at phenotypic and genotypic level and showed that genotypic correlation was higheer than the respective phenotypic correlation in most of the cases suggesting strong inherent association between the characters under study (Table 2). Similar result was found by Pankaj et al, (2002). Lower phenotypic correlation coefficients than genotypic correlation coefficients indicate that both environmental and genotypic correlations in those cases act in same direction, and finally maximize their expression at phenotypic level.

In present investigation, number of female flowers/plant gave the highest significant positive association with fruit yield/plant $\left(r_{\mathrm{g}}=0.918, \mathrm{r}_{\mathrm{p}}=0.839\right)$. In addition, fruit yield/plant was also correlated positively and significantly with number of male flowers $\left(r_{g}=0.687, r_{p}=0.638\right)$. This means that increase in the number of male and female flowers would result in higher pollen production and therefore, enhance fertilization and ultimately fruit yield/plant. Shah and Kale (2002) reported close association and dependency of yield with number of female flowers.

A significant positive correlation was also obtained between number of male flowers and number of female flowers $\left(r_{g}=0.852, r_{p}=0.769\right)$. This suggests that the number of male and female flowers increases or decreases simultaneously, and these could be linked to enhance pollination efficiency in the plant. Positive genetic correlation was reported between the number of male and female flowers in pumpkin (Aruah et al., 2012)

On the other hand, the number of male flowers was correlated significantly and negatively with days to first male flowering $\left(r_{g}=-0.597, r_{p}=-0.410\right)$ and days to first female flowering $\left(r_{g}=-0.443, r_{p}=-0.329\right)$. Similar result was found in case of number of female flowers. These results indicated that early flowering increased the number of male and female flowers and increased number of male and female flowers which increased yield/plant. This result was in agreement with Mohanty (2001) who reported that early flowering at lower nodes and higher number of flowers/plant, particularly the female flower, increase fruit yield. Badade et al, (2001) found negative association of yield/ vine with days to first male flower opening. 


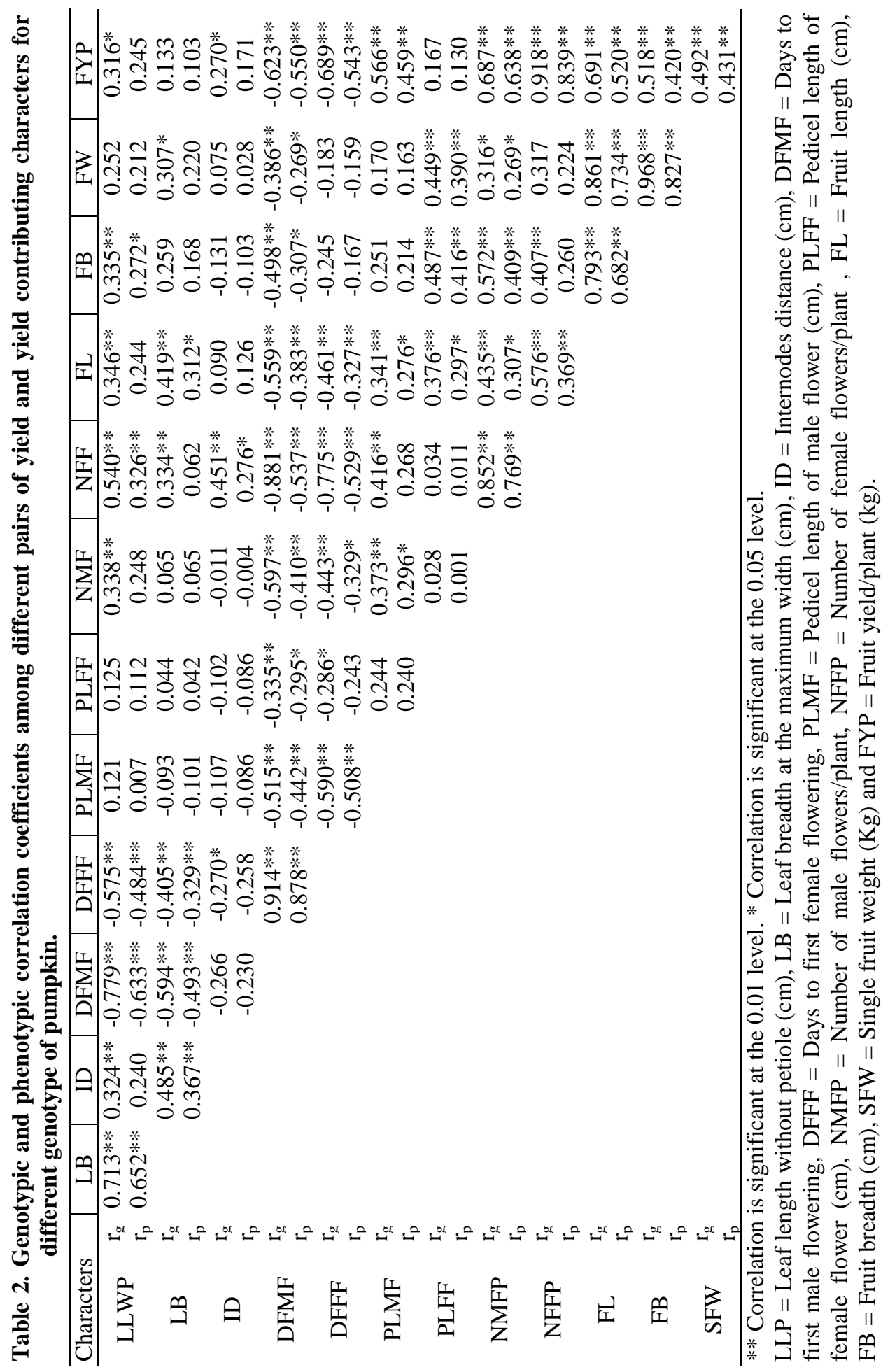


The positive and strong associations of fruit length $\left(r_{g}=0.691, r_{p}=0.520\right)$, fruit breadth $\left(r_{g}=0.518, r_{p}=0.420\right)$ and single fruit weight $\left(r_{g}=0.492, r_{p}=0.431\right)$ with fruit yield/plant revealed the importance of the characters in determining fruit yield/plant, and showed that selection for these traits would result in superior fruit yield. However, pedicel length of female flower had non significant correlations with most of the agronomic traits evaluated which indicated that it had minimal and non-significant contributions to the crops fruit yield and development.

This picture becomes more clear when correlation co-efficient was partitioned into direct and indirect effects by path analysis both at genotypic and phenotypic levels.

Path co-efficient analysis: The path co-efficient analysis revealed that the highest positive direct effect was recorded in number of female flowers $(0.887)$. The positive and significant correlation $\left(\mathrm{r}_{\mathrm{g}}=0.918 * *\right)$ obtained between number of female flowers and fruit yield/plant was because of the contribution of this direct effects to fruit yield/plant. Aruah et al (2012) reported high positive direct effect of number of female flowers on weight of fruit/plant. Similarly, days to first female flowering showed highly significant but negative correlation with fruit yield/plant due to high direct effect (0.798) to fruit yield/plant. Thus, a dependable trait for the improvement of pumpkin. Although the direct selection of fruit length (0.381) and single fruit weight (0.318) had a high contribution to fruit yield/plant, the indirect selections of fruit length via days to first male flowering (0.814), number of female flowers (0.511), single fruit weight (0.273) and the indirect selection of single fruit weight via days to first male flowering (0.562), number of female flowers $(0.281)$, fruit length $(0.328)$ could also be adopted for improving the fruit yield. Fruit breadth was observed to have the highest positive indirect effect (0.899), but high negative direct effect which ultimately show highly significant positive correlation $\left(0.518^{* *}\right)$ (Table 3$)$. In such a situation indirect factors are to be considered simultaneously for selection. The path diagrams are presented in Fig.1.

Leaf breadth (-0.224) and pedicel length of female flower (-0.157) were observed to have high negative direct effects on fruit yield/plant. However, the high indirect effects of these characters on fruit yield/plant. However the high indirect effects of these characters on fruit yield/plant did not produce significant correlations between the fruit yield/plant and above traits due to the masking effect and suppressing action of their direct effect.

Through path analysis the residual effect $(0.38)$ was observed which indicated that the characters under study contributed $62 \%$ of the fruit yield plant ${ }^{-1}$ (Table 3 ). It is suggested that there were some other factors those contributed $38 \%$ to the fruit yield plant ${ }^{-1}$ not included in the present study. 


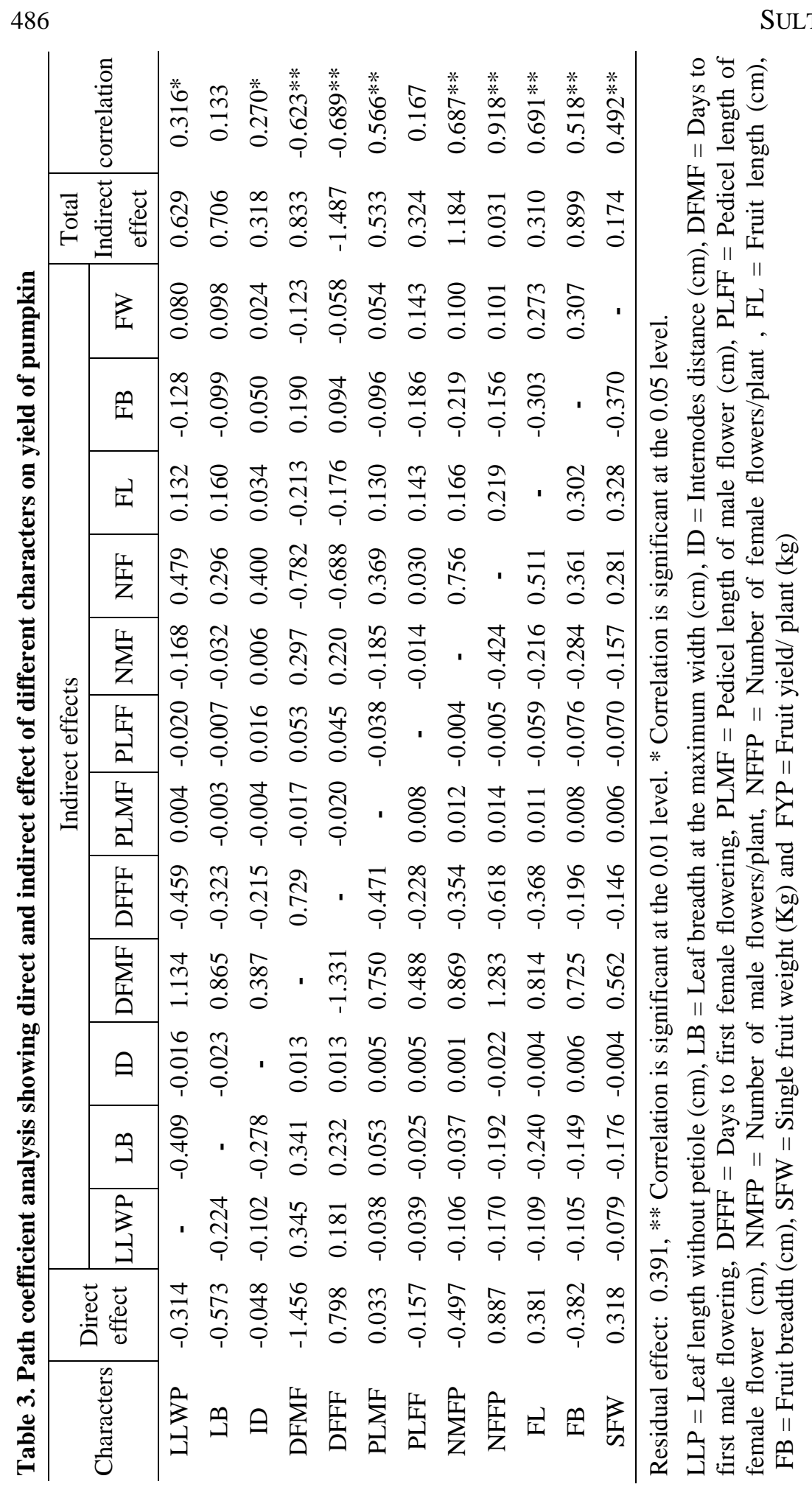




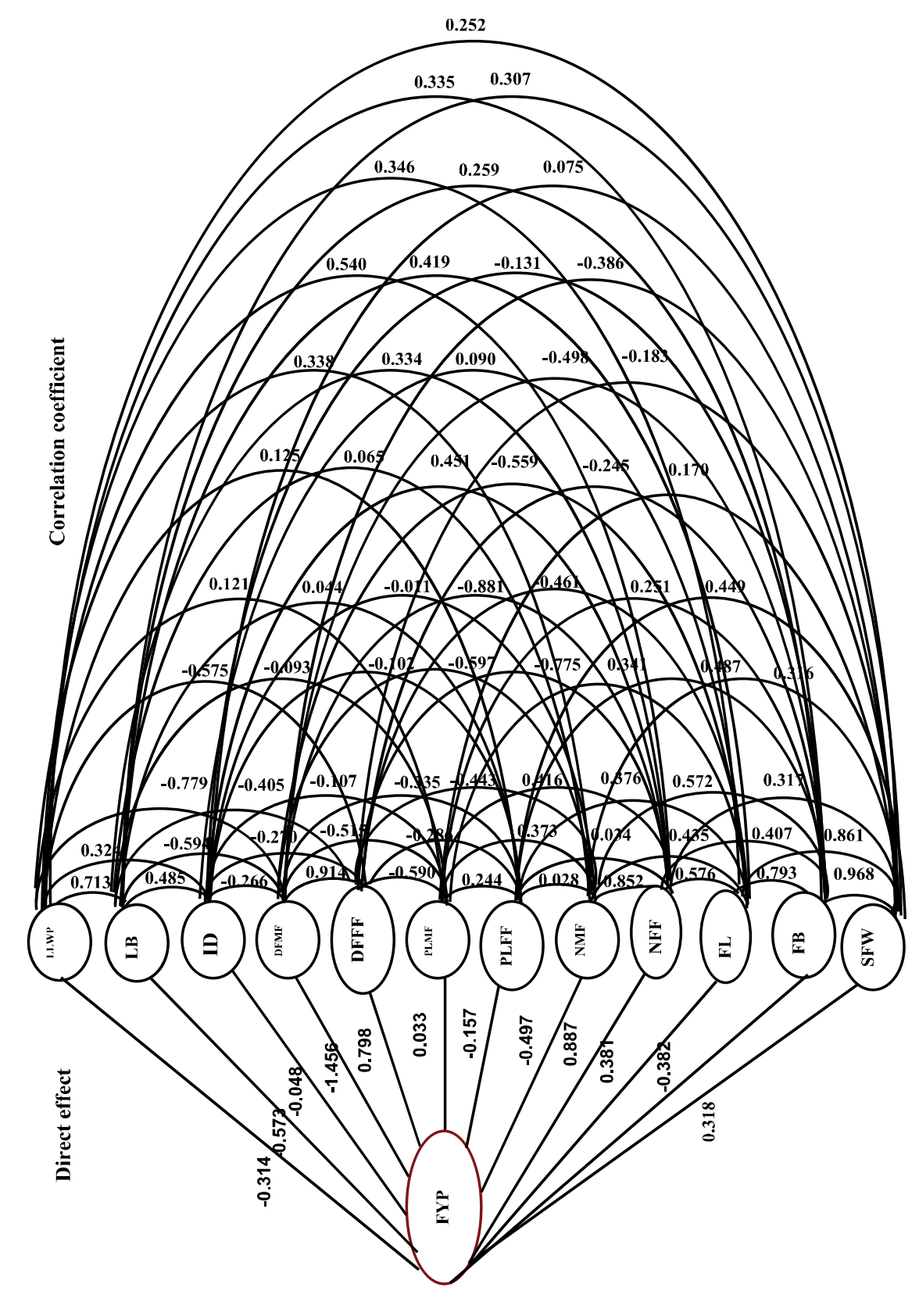


Wide genetic variability was found among the genotypes. After analyzing the data obtained from genotypic co-efficient of variation, phenotypic co-efficient of variation, heritability, genetic advance in percent of mean, correlation coefficient and path co-efficient analysis, it can be concluded that days to first female flowering, number of female flowers, fruit length, fruit breadth and single fruit weight can be used as selection criteria to increase fruit yield/plant in pumpkin.

\section{References}

Abd El-Aziz, A. B. and H.H. Abd El-Kalek. 2011. Antimicrobial proteins and oil seeds from pumpkin (Cucurbita moschata). Nature and Science 9(3): 105-119.

Aliu, S., A. Haziri, S. Fetahu, N. Aliage, I. Rusinove, I. Haziri and V. Arapi. 2011. Morphological and nutritive variation in a collection of Cucurbita pepo L. growing in Kosova. Notulae Scientia Biologicae 3(2): 119-122.

Aruah, C. B., M. I. Uguru and B.C. Oyiga . 2010. Nutritional evaluation of some Nigerian pumpkins (Cucurbita spp.) Fruit, vegetable and Cereal Science and Biotechnology 5 (Special Issue 2): 64-71

Aruah, C. B., M. I. Uguru, and B.C. Oyiga. 2012. Genetic Variability and InterRelationship among some Nigerian Pumpkin Accessions ( Cucurbita spp.). International Journal of Plant Breeding 6(1): 34-41.

Badade, D.S., S. D. Warade and S.K. Gaikwad. 2001. Correlation studies in bottle gourd (Lageneria sicereria (Mol.) Stand). Journal of Maharashtra Agricultural Universities 26(1):20-22.

BBS. (Bangladesh Bureau of Statistics). 2011. Statistical Year Book of Bangladesh 20102011. Bangladesh Bureau of Statistics Division, Ministry of Planning, Govt.of the people's Republic of Bangladesh, Dhaka.

Burton, G.W. 1952. Quantitative inheritance in grasses. Proceeding 6th International Grassland Congress, Pennsylvania. 17-23 August. Pennsylvania State College, State College, Pennsylvania, USA. P. 277-283.

Chowdhury, D. and K. C. Sharma. 2002. Studies on variability, heritability, genetic advance and correlation in ridge gourd (Luffa acutangula Roxb.). Hort. J. 15(3): 53-58.

Dewey, D.R. and K. H. Lu. 1959. A correlation and path coefficient analysis of components of crested wheat grass seed production. Agron. J. 51:515-518.

Fu, C-L., S.H. Huan, Q.H. Li. 2006. A Review on pharmacological activities and utilization technologies of pumpkin. Plant Foods for Human Nutrition Journal 61: 70-77

Johnson, H.W., H.F. Rabinson, and R.E. Comstock. 1955. Estimation of genetic and environmental variability in soybean. Agron. J. 47:314-318.

Li Q-H, Z. Tian, T-Y Cai. 2003. Study on the hypoglycemic action of pumpkin extract in diabetic rats. Acta Nutrimental Sinica 25: 34-36. 
Miller, P.A., J.G. Williams, H.F. Robinson, and R.E. Comstock. 1958. Estimates of genotypic and environmental variances and co-variances in upland cotton and their implication in selections. Agron. J. 501:126-131.

Mohanty, B. K. 2001. Studies on correlation and path analysis in pumpkin (Cucurbita moschata). Haryana J. Hort. Sci. 30(1/2): 86-89.

Nkosi C.Z., A.R. Opoku, S.E. Terblanche. 2006. Antioxidant effects of pumpkin seeds (Cucurbita pepo) protein isolate in CCI-induced liver injury in low-protein fed rats. Phototherapy Research 20: 935-940.

Pankaj, S., T. Gyanendra, A.S. Gontia, V.D. Patil, and P. Shah. 2002. Correlation studies in Indian Mustard. Agricultural Science Digest 22(2):79-82.

Robinson, H. I., R. E. Comstock, and P. H. Harvey. 1949. Estimation of heritability and degree of dominance in corn. Agron. J. 41:353-359.

Saha, R. R., B. N. Mitra, A. E. Hossain, M. Jamaluddin and A. M. M. Mosiul Hoque. 1992. Genetic variability, character association and path coefficient analysis in pumpkin (Cucurbita moschata L.). Bangladesh Hort., 20(1), 59-62.

Shah, S.R. and P.N. Kale. 2002. Yield component association analysis in ridge gourd. J. Maharashtra Agril. Univ., 27(2): 197-198.

Shivasubramanian, S. and M. Menon. 1973. Heterosis and inbreeding depression in rice. The Madras Agricultural Journal 6:1139-1140.

Singh, G. and T. Lal. 2005. Genetic variability, heritability and genetic advance for yield and its contributing traits in muskmelon (Cucumis melo L.). J. Res. Punjab Agric. Univ. 42(2): 168-174.

Singh, R.K. and B.D. Chaudhury. 1985. Biometrical Methods in Quantitative Genetic Analysis. Kalyani Publishers, New Delhi, India. p.56.

Ushakumari, R.M., M. Subramanian, and Subramaniam. 1991. Studies on coefficient of variation and heritable components of some quantitative characters of Brinjal. Indian Journal of Horticulture 48(1):75-78. 